\title{
HUBUNGAN PEMBERIAN IMUNISASI BCG DENGAN KEJADIAN TUBERKULOSIS PADA ANAK DI PUSKESMAS PANDIAN KABUPATEN SUMENEP
}

\author{
Rhesa Dwi Arianti Rachim \\ Rumah Sakit Karsa Husada, Bali
}

\begin{abstract}
ABSTRAK
Hubungan Pemberian Imunisasi BCG dengan Kejadian Tuberkulosis pada Anak di Puskesmas Pandian Kabupaten Sumenep. Tuberkulosis saat ini masih menjadi masalah kesehatan global. Di Jawa Timur (2012) terdapat sekitar 41.000 kasus, Kabupaten Sumenep menyumbang 11\% kasus dan 4\% kasus tuberkulosis anak. Untuk menurunkan prevalensi tuberkulosis dilakukan imunisasi BCG. Mengetahui hubungan pemberian imunisasi BCG dengan kejadian tuberkulosis pada anak di Puskesmas Pandian Kabupaten Sumenep. Penelitian ini merupakan penelitian Non Eksperimental dengan desain case-control study (retrospekstif). Sampel yang digunakan berjumlah 58 anak (29 kasus dan 29 kontrol). Data diperoleh dari rekam medis dan wawancara kepada orang tua. Penelitian ini menggunakan analisis bivariat dengan uji statistik Chi Square. Pada kelompok kasus didapatkan anak yang imunisasi BCG sebanyak 21 anak (72.4\%) dan yang belum sebanyak 8 anak (27.6\%). Pada kelompok kontrol, anak yang imunisasi BCG sebanyak 28 anak (96.6\%) dan 1 anak (3.4\%) yang belum diimunisasi. Hasil tabulasi silang imunisasi BCG dengan kejadian tuberkulosis anak adalah $X^{2}=6.444, p$ value $=0.011$ dan Odd ratio $(\mathrm{OR})=0.094 ;$ CI 95\% $=0.011-0.808$ dan PAR $=9.98 \%$. Ada hubungan antara pemberian imunisasi BCG dengan kejadian tuberkulosis pada anak di Puskesmas Pandian Kabupaten Sumenep. Imunisasi BCG merupakan faktor protektif terhadap tuberkulosis anak dan dapat mencegah tuberkulosis sekitar 10\% pada populasi sampel.
\end{abstract}

\section{ABSTRACT}

The Relationship between BCG Immunization with Tuberculosis in Children in Pandian Health Centre, Sumenep Regency. Tuberculosis is still a global health problem. In East Java (2012) there were approximately 41,000 cases, Sumenep accounted for 11\% of cases and 4\% of cases of tuberculosis children. BCG immunization is done to reduce the prevalence of tuberculosis. This Study was carried out to determine the relationship of giving BCG immunization with the incidence of tuberculosis in children at Pandian health center District of Sumenep. This study is the Non-Experimental research with case-control study design (retrospective). The samples used were 58 children $(29$ cases and 29 controls). Data were obtained from medical records and interviews of the parents. This study used bivariate analysis with Chi Square statistical test. In the case group obtained the data of children who have received BCG immunization were 21 children (72.4\%) and who have not were 8 children (27.6\%). In the control group, children who have received BCG immunization as many as 28 children (96.6\%) and 1 child (3.4\%) who bas not been immunized. The results of cross-tabulation between BCG immunization with the incidence of tuberculosis child is $X 2=6.444$, $p$-value $=0.011$ and $\mathrm{OR}=0.094 ; 95 \% C I=0011-0808$ and $\mathrm{PAR}=9.98 \%$. There is a correlation between BCG immunization with the incidence of tuberculosis in children at Pandian bealth center District of Sumenep. $B C G$ is a protective factor against tuberculosis children and can prevent tuberculosis was $10 \%$ in the sample population.

Ke ywords: BCG Immunization, Tuberculosis Children.

\section{PENDAHULUAN}

Penyakit tuberkulosis sampai saat ini masih menjadi masalah kesehatan global. Kasus terbanyak didapatkan pada populasi laki-laki, namun dilaporkan prevalensi penyakit ini juga banyak pada populasi perempuan dan anak-anak, diperkirakan terdapat 410.000 orang perempuan dan 74.000 anak meninggal akibat penyakit ini (WHO, 2013a). Indonesia masih masuk ke dalam lima negara dengan kasus tuberkulosis terbanyak. Di Jawa Timur terdapat sekitar 41.000 kasus tuberkulosis pada tahun 2012, Kabupaten Sumenep menyumbang sekitar 11\% kasus dan 4\% kasus tuberkulosis anak (Dinkes Jatim, 2012). Pencegahan vaksinasi terhadap penyakit tuberkulosis adalah vaksinasi Bacillus Calmette Guerin (BCG), yang telah diwajibkan di 64 negara dan direkomendasikan di beberapa negara lainnya. Indonesia telah melaksanakannya sejak tahun 1952 (Rahajoe, et al., 2008).

Penelitian tentang hubungan antara imunisasi BCG dan tuberkulosis pada anak sudah banyak dilakukan. Namun hasil akhir penelitian berbeda. Penelitian invitro yang dilakukan Tjahajati (2005) pada kucing menyimpulkan vaksinasi BCG dapat meningkatkan secara bermakna respon imun seluler yaitu melalui peningkatan aktivitas makrofag baik dalam aktifitas fagositosis maupun sekresi Reactive Oxygen Intermediate (ROI).

Berdasarkan masalah diatas penelitian ini bertujuan untuk mengetahui hubungan pemberian Imunisasi BCG dengan kejadian tuberkulosis pada anak di Puskesmas Pandian 
Kabupaten Sumenep. Manfaat yang diharapkan dari penelitian ini adalah memberikan informasi tentang imunisasi BCG dan angka kejadian tuberkulosis pada anak untuk membantu upaya peningkatan mutu kualitas pelayanan kesehatan pada masyarakat, serta memberi tambahan informasi kepada masyarakat tentang penyakit tuberkulosis pada anak, mulai dari gejala, diagnosis dan terapinya. Serta memberikan informasi tentang pentingnya imunisasi BCG pada anak.

\section{METODE}

Penelitian ini merupakan penelitian Non Eksperimental dengan desain penelitian studi kasus-kontrol (case-control study) yang bersifat retrospektif (Suradi, et al., 2011). Penelitian dilakukan di Puskesmas Pandian Kabupaten Sumenep pada tanggal 24 Februari sampai 1 Maret 2014.

Populasi dalam penelitian ini adalah semua anak yang menjalani pengobatan di Puskesmas Pandian Kabupaten Sumenep mulai tanggal 1 Januari 2013 sampai 31 Desember 2013. Sampel yang digunakan pada penelitian ini adalah anak yang menjalani pengobatan di Puskesmas Pandian Kabupaten Sumenep mulai tanggal 1 Januari sampai 31 Desember 2013 yang memenuhi kriteria inklusi dan eksklusi. Teknik pengambilan sampel pada penelitian ini adalah dengan menggunakan teknik Consecutive Sampling dengan kriteria inklusi dan eksklusi. Untuk menentukan besar sampel pada penelitian ini menggunakan rumus besar sampel studi kasus-kontrol tidak berpasangan yaitu :

$$
n 1=n 2=\frac{(z \alpha \sqrt{2 P Q}+z \beta \sqrt{P 1 Q 1+P 2 Q 2})^{2}}{(P 1-P 2)^{2}}
$$

Kesalahan tipe I : 5\%, maka $z \alpha=1,64$

Kesalahan tipe II : $20 \%$, maka $z \beta=0,84$

$\mathrm{P} 2=$ proporsi pajanan pada kelompok kasus sebesar 0,01

(Dinkes Jatim, 2012)

$\mathrm{Q} 2=1-0,01=0,99$

$\mathrm{P} 1-\mathrm{P} 2=0,2$ (ditetapkan)

$\mathrm{P} 1=\mathrm{P} 2+0,2=0,21$

$\mathrm{Q} 1=1-0,21=0,79$

$\mathrm{P}=1 / 2(\mathrm{P} 1+\mathrm{P} 2)=1 / 2(0,21+0,01)=0,11$

$\mathrm{Q}=1-\mathrm{P}=1-0,11=0,89$

Maka, didapatkan jumlah sampel minimal yang harus dipenuhi adalah sebesar 29 sampel untuk kelompok kasus. Sehingga pada penelitian ini diambil sampel sebanyak 29 sampel kelompok kasus dan 29 sampel kelompok kontrol.

Kriteria inklusi kelompok kasus dari penelitian ini adalah anak usia 1-10 tahun yang didiagnosis tuberkulosis berdasarkan rekam medis dan menjalani pengobatan di Puskesmas Pandian Kabupaten Sumenep dan bersedia menjadi subyek penelitian. Sedangkan kriteria eksklusi kelompok kasus dari penelitian ini adalah tidak memiliki KMS dan orang tua atau keluarganya tidak mengingat tanggal lahir dan imunisasi apa yang sudah diberikan pada anak. Untuk kriteria inklusi kelompok kasus dari penelitian ini adalah anak usia 1-10 tahun yang tidak sakit tuberkulosis dan menjalani pengobatan di Puskesmas Pandian Kabupaten Sumenep dan bersedia menjadi subyek penelitian. Kriteria eksklusi kelompok kontrol dari penelitian ini adalah tidak memiliki KMS dan orang tua atau keluarganya tidak mengingat tanggal lahir dan imunisasi apa yang sudah diberikan pada anak.

Alat ukur dan alat bantu yang digunakan untuk penelitian ini adalah, rekam medik anak dan kartu menuju sehat (KMS) anak. Rekam medik digunakan untuk mengetahui diagnosis penyakit anak. Diagnosis tuberkulosis pada anak dengan system scoring. Kartu Menuju Sehat digunakan untuk evaluasi tanggal lahir dan imunisasi yang telah diberikan kepada anak. Dan rekam medik digunakan untuk mengetahui diagnosis tuberkulosis pada anak.

Ada dua macam data, yaitu: data primer dan sekunder. Pertama dilakukan pengambilan data sekunder terlebih dahulu untuk mencari kelompok kasus dan kontrol. Data sekunder pada penelitian ini adalah data dari rekam medis anak di Puskesmas Pandian Kabupaten Sumenep. Setelah ditentukan kelompok kasus dan kelompok kontrol berdasarkan data sekunder, kemudian dilakukan pengambilan data primer yaitu data yang diperoleh secara langsung dari sampel penelitian, dalam penelitian ini merupakan data hasil wawancara dengan orang tua anak sampel penelitian.

Penelitian ini menggunakan analisis bivariat untuk mengidentifikasi ada tidaknya hubungan variabel bebas (pemberian imunisasi BCG) dengan variabel terikat (kejadian tuberkulosis paru pada anak). Uji statistik yang digunakan adalah Chi Square. Untuk mengukur hubungan antara faktor risiko dan penyakit dilakukan perhitungan Odds Ratio (OR) dengan interval kepercayaan 95\%.

\section{HASIL DAN PEMBAHASAN}

Penelitian ini merupakan penelitian observasional dengan desain case-control study bersifat restrospektif yang membuktikan adanya hubungan antara pemberian imunisasi BCG dengan kejadian tuberkulosis pada anak di Puskesmas Pandian Kabupaten Sumenep. Pada penelitian ini terdapat 2 kelompok sampel penelitian, yaitu: kelompok kasus (anak dengan tuberkulosis) dan kelompok kontrol (anak tidak dengan tuberkulosis). Diagnosis tuberkulosis didapatkan dari data rekam medis anak di Puskesmas Pandian, sedangkan status imunisasi BCG anak didapatkan dari data hasil wawancara dengan orang tua anak. Diagnosis tuberkulosis pada anak di Puskesmas Pandian Sumenep menggunakan sistem skoring tuberkulosis.

Penelitian ini dilakukan di Puskesmas Pandian Kabupaten Sumenep pada tanggal 24 Februari-1 Maret 2014, dengan jumlah sampel sebanyak 58 anak yang terdiri dari 29 anak sebagai kelompok kasus dan 29 anak sebagai kelompok kontrol. Kelompok kasus merupakan kelompok anak-anak yang didiagnosis tuberkulosis berdasarkan rekam medis dan menjalani pengobatan di Puskesmas Pandian Kabupaten Sumenep dalam rentang waktu 1 Januari sampai 31 Desember 2013. Kelompok kontrol merupakan kelompok anak-anak yang tidak sakit tuberkulosis dan menjalani pengobatan di Puskesmas Pandian Kabupaten Sumenep dalam rentang waktu 1 Januari sampai 31 Desember 2013. Adapun karakteristik sampel dapat dilihat pada tabel 1 dibawah ini: 


\begin{tabular}{lcrrrrr}
\hline \multirow{2}{*}{ Karakteristik } & \multicolumn{2}{c}{ Kasus } & \multicolumn{2}{c}{ Kontrol } & \multicolumn{2}{c}{ Total } \\
\cline { 2 - 7 } & $\mathrm{N}$ & $\%$ & $\mathrm{~N}$ & $\%$ & $\mathrm{~N}$ & $\%$ \\
\hline Jenis Kelamin & 14 & $48.3 \%$ & 15 & $51.7 \%$ & 29 & $100 \%$ \\
Laki-laki & 15 & $51.7 \%$ & 14 & $48.3 \%$ & 29 & $100 \%$ \\
$\begin{array}{l}\text { Perempuan } \\
\text { Umur }\end{array}$ & 17 & $45.9 \%$ & 20 & $54.1 \%$ & 37 & $100 \%$ \\
$\begin{array}{l}1-5 \text { tahun } \\
\text { 6-10 tahun }\end{array}$ & 12 & $57.1 \%$ & 9 & $42.9 \%$ & 21 & $100 \%$ \\
Status Imunisasi BCG & & & & & & \\
Imunisasi BCG & 21 & $42.9 \%$ & 28 & $57.1 \%$ & 49 & $100 \%$ \\
Tidak Imunisasi BCG & 8 & $88.9 \%$ & 1 & $11.1 \%$ & 9 & $100 \%$ \\
\hline Sumber: Data primer, 2014) & & & & & &
\end{tabular}

(Sumber : Data primer, 2014)

Berdasarkan tabel 1 karakteristik sampel penelitian menurut jenis kelamin diketahui bahwa jumlah total anak laki-laki dalam penelitian sebanding dengan jumlah anak perempuan, yaitu 29 orang anak laki-laki dan 29 anak perempuan. Jumlah anak laki-laki pada kelompok kasus sebanyak 14 anak $(48.3 \%)$ dan pada kelompok kontrol sebanyak 15 anak (51.7\%). Sedangkan jumlah anak perempuan pada kelompok kasus sebanyak 15 anak (51.7\%) dan pada kelompok kontrol sebanyak 14 anak (48.3\%).

Umur sampel penelitian dibagi dalam 2 kelompok, yaitu umur balita (1-5 tahun) dan umur anak-anak (6-10 tahun). Hal ini berdasarkan pembagian umur menurut Depkes RI tahun 2009. Berdasarkan data yang didapatkan pada penelitian ini diketahui bahwa umur balita (1-5 tahun) merupakan umur sampel terbanyak, yaitu 37 anak terdiri dari 17 anak (45.9\%) pada kelompok kasus dan 20 anak (54.1\%) pada kelompok kontrol. Untuk umur anak-anak (6-10 tahun) pada penelitian ini terdapat 21 anak terdiri dari 12 anak (57.1\%) pada kelompok kasus dan 9 anak (42.9\%) pada kelompok kontrol.

\section{Imunisasi BCG}

Berdasarkan hasil penelitian secara keseluruhan, kelompok kasus dan kelompok kontrol didapatkan sebagian besar sampel sudah mendapatkan imunisasi BCG yaitu sebanyak 49 anak $(84.5 \%)$ dan hanya sebagian kecil yang belum mendapatkan imunisasi BCG yaitu sebanyak 9 anak (15.5\%). Jika dibagi berdasarkan kelompok didapatkan data pada kelompok kasus terdapat 21 anak $(72.4 \%)$ yang sudah mendapat imunisasi BCG dan 8 anak (27.6\%) yang belum mendapatkan imunisasi BCG. Sedangkan pada kelompok kontrol hampir semua anak sudah mendapatkan imunisasi BCG, yaitu 28 anak (96.6\%) dan hanya 1 anak (3.4\%) yang belum mendapatkan imunisasi BCG. Pemberian imunisasi BCG merupakan bagian dari faktor imunisasi yang dianalisa untuk memprediksi kejadian tuberkulosis pada anak. Imunisasi BCG dapat melindungi anak dari meningitis TB dan TB milier dengan efek proteksi atau efektivitas BCG bervariasi dari 0-80\%, dari berbagai negara (Said \& Boediman, 2010).

\section{Kejadian Tuberkulosis pada Anak}

Penelitian yang telah dilakukan mengambil sampel sebanyak 58 anak dengan 29 anak kelompok kasus dan 29 anak kelompok kontrol. Kelompok kasus merupakan kelompok anak yang mengalami tuberkulosis. Data tuberkulosis pada anak diperoleh dengan melihat rekam medis anak. Tuberkulosis pada anak merupakan penyakit infeksi menular yang disebabkan oleh bakteri tahan asam, yaitu Mycobacterium tuberculosis yang terjadi pada anak (Price \& Standridge, Tuberkulosis Paru, 2006).
Tuberkulosis pada anak sulit untuk didiagnosis karena 2 hal, yaitu sifat kuman yang peubacillary (jumlah bakteri sedikit) dan sulitnya pengambilan spesimen. Oleh karena itu, penegakan diagnosis tuberkulosis pada anak didapatkan dengan sistem skoring tuberkulosis dengan skor maksimal 13 dan dinyatakan positif tuberkulosis jika skor ?6 dan negatif jika $<5$ (Rahajoe \& Setyanto, 2010a). Puskesmas Pandian Kabupaten Sumenep juga memakai sistem skoring dalam penegakan diagnosis tuberkulosis pada anak.

\section{Hubungan Antara Jenis Kelamin dengan Tuberkulosis pada Anak}

Tabel 2 Hubungan Antara Jenis Kelamin dengan Tuberkulosis pada Anak

\begin{tabular}{|c|c|c|c|c|}
\hline \multirow{2}{*}{$\begin{array}{c}\text { Jenis } \\
\text { Kelamin }\end{array}$} & \multicolumn{2}{|c|}{ Tuberkulosis } & \multirow{2}{*}{ Total } & \multirow{2}{*}{ Chi-Square } \\
\hline & $\mathrm{Ya}$ & Tidak & & \\
\hline \multirow{2}{*}{ Laki-laki } & 14 & 15 & 29 & \multirow{6}{*}{$\begin{array}{l}\chi^{2}=0.069 \\
p=0.793\end{array}$} \\
\hline & $48.3 \%$ & $51.7 \%$ & $100 \%$ & \\
\hline \multirow{2}{*}{ Perempuan } & 15 & 14 & 29 & \\
\hline & $51.7 \%$ & $48.3 \%$ & $100 \%$ & \\
\hline \multirow{2}{*}{ Total } & 29 & 29 & 58 & \\
\hline & $50 \%$ & $50 \%$ & $100 \%$ & \\
\hline
\end{tabular}

(Sumber : Data primer dan sekunder, 2014)

Berdasarkan tabel 2 jumlah sampel yang mengalami tuberkulosis sebanyak 29 anak, terdiri dari 14 anak laki-laki dan 15 anak perempuan. Sedangkan jumlah sampel yang tidak mengalami tuberkulosis juga 29 anak, terdiri dari 15 anak laki-laki dan 14 anak perempuan.

Hasil tabulasi silang pada hubungan antara jenis kelamin dengan tuberkulosis pada anak didapatkan nilai Chi-square hitung sebesar 0.069 dengan signifikansi sebesar 0.793 . Hal ini menunjukkan bahwa tidak terdapat hubungan antara jenis kelamin dengan tuberkulosis pada anak karena nilai Chi-square hitung lebih kecil dari pada Chi-square tabel (3.841) dan nilai signifikansi lebih besar dari 0.05.

Distribusi sampel menurut jenis kelamin pada penelitian ini menunjukkan hasil yang hampir sebanding antara lakilaki dan perempuan baik secara keseluruhan maupun pada kelompok kasus dan kelompok kontrol.

Hasil analisis data jenis kelamin dan tuberkulosis pada anak menggunakan uji Chi-square menunjukkan hasil tidak ada hubungan antara jenis kelamin dengan kejadian tuberkulosis pada anak karena nilai Chi-square hitung lebih kecil dari pada Chi-square tabel (3.841) dan nilai signifikansi lebih besar dari 0.05 . Hasil penelitian ini sejalan dengan penelitian yang dilakukan oleh Sari pada tahun 2009 di RS Khusus Paru Surabaya yang menyatakan bahwa tidak ada hubungan antara jenis kelamin dengan kejadian tuberkulosis (Sari, 2009). Hal ini sama juga dengan hasil penelitian di 
Jakarta Timur yang dilakukan oleh Herawati et.al pada tahun 2002 menyatakan bahwa tidak ada hubungan antara jenis kelamin dengan kejadian tuberkulosis (Herawati, et al., 2002). Sehingga jenis kelamin laki-laki dan perempuan memiliki risiko yang sama untuk terjangkit penyakit tuberkulosis.

\section{Hubungan Antara Umur dengan Tuberkulosis pada Anak}

Berdasarkan tabel 3 jumlah sampel yang berumur 1-5 tahun sebanyak 37 anak, terdiri dari 17 anak (45.9\%) yang mengalami tuberkulosis dan 20 anak (54.1\%) yang tidak mengalami tuberkulosis. Sedangkan sisanya, sampel yang berumur 6-10 tahun terdapat 21 anak, terdiri dari 12 anak (57.1\%) yang mengalami tuberkulosis dan 9 anak (42.9\%) yang tidak mengalami tuberkulosis.

Hasil tabulasi silang pada hubungan antara status imunisasi BCG dengan tuberkulosis pada anak didapatkan nilai Chi-square hitung sebesar 0.672 dengan signifikansi sebesar 0.412. Hal ini menunjukkan bahwa tidak terdapat hubungan antara umur anak dengan tuberkulosis pada anak karena nilai Chi-square hitung lebih kecil dari pada Chi-square tabel (3.841) dan nilai signifikansi lebih besar dari 0.05.

Penelitian ini mengambil kriteria inklusi yaitu umur anak antara 1 sampai 10 tahun, karena pada umur 1 tahun atau lebih diharapkan anak sudah mendapat imunisasi BCG dan umur 10 tahun karena suatu studi yang dilakukan oleh Sterne dkk. yang dikutip oleh Said dan Budiman (2010), menemukan bahwa efektivitas BCG menurun seiring berjalannya waktu sejak vaksinasi, selain itu juga tidak ditemukan bahwa BCG dapat memberikan perlindungan setelah lebih dari 10 tahun sejak vaksinasi. Kemudian umur anak pada penelitian ini dibagi ke dalam 2 kelompok umur, yaitu: umur 1-5 tahun dan umur 6-10 tahun. Hal ini sesuai dengan pembagian umur menurut DEPKES RI tahun 2009 yaitu: umur 1-5 tahun termasuk kategori balita dan umur 6-11 tahun termasuk kategori anak-anak (DEPKES RI, 2009).

Dari data tersebut dapat didiskripsikan dalam penelitian ini sampel terbanyak yang mengalami tuberkulosis terdapat pada rentang umur 1-5 tahun. Namun secara statistik umur anak pada penelitian ini tidak ada hubungan dengan kejadian tuberkulosis. Hal ini ditunjukkan dengan hasil tabulasi silang pada hubungan antara jenis kelamin dengan tuberkulosis pada anak didapatkan nilai Chi-square hitung sebesar 0.069 dengan signifikansi sebesar 0.793. Hasil penelitian ini tidak sejalan dengan penelitian yang dilakukan oleh Kuswantoro tahun 2002, yang menyatakan bahwa kelompok usia $<5$ tahun merupakan kelompok usia dengan risiko tinggi terkena tuberkulosis anak karena status imunitas selulernya masih belum berkembang sempurna (imatur). Akan tetapi, faktor risiko ini akan berkurang seiring dengan bertambahnya usia (Kuswantoro, 2002). Penelitian yang dilakukan Fitriani pada tahun 2012 juga mendapatkan hasil yang bertolak belakang dengan penelitian ini, yaitu ada hubungan antara umur dengan kejadian tuberkulosis dan umur balita lebih berisiko terkena tuberkulosis (Fitriani, 2012).

Perbedaan hasil penelitian ini dengan penelitian sebelumnya dapat dikarenakan distribusi sampel menurut umur pada penelitian ini tidak jauh berbeda, pada umur 15 tahun terdapat 17 anak dan pada umur 6-10 tahun terdapat 12 anak sehingga secara statistik tidak didapatkan hubungan antara umur dan kejadian tuberkulosis, namun secara deskriptif terdapat perbedaan. Selain itu, penelitian ini mengambil teknik pengambilan sampel secara Consecutive sampling sehingga tidak dapat menggambarkan keseluruhan karakteristik penderita tuberkulosis anak di Puskesmas Pandian Kabupaten Sumenep.

\section{Hubungan Antara Status Imunisasi BCG dengan Tuberkulosis pada Anak}

Tabel 3 Hubungan Antara Umur dengan Tuberkulosis pada Anak

\begin{tabular}{ccccc}
\hline \multirow{2}{*}{ Umur } & \multicolumn{2}{c}{ Tuberkulosis } & \multirow{2}{*}{ Total } & \multirow{2}{*}{ Chi-Square } \\
\cline { 2 - 3 } & Ya & Tidak & & \\
\hline \multirow{2}{*}{ 1-5 tahun } & 17 & 20 & 37 & \\
& $45.9 \%$ & $54.1 \%$ & $100 \%$ & \\
6-10 tahun & 12 & 9 & 21 & $\chi^{2}=0.672$ \\
& $57.1 \%$ & $42.9 \%$ & $100 \%$ & $\mathrm{p}=0.412$ \\
Total & 29 & 29 & 58 & \\
& $50 \%$ & $50 \%$ & $100 \%$ & \\
\hline
\end{tabular}

(Sumber : Data primer dan sekunder, 2014)

Berdasarkan tabel 4 jumlah sampel yang mengalami tuberkulosis dan sudah mendapatkan imunisasi BCG sebanyak 21 anak (42.9\%), sedangkan sampel yang tidak mengalami tuberkulosis dan sudah mendapatkan imunisasi BCG sebanyak 28 anak (57.1\%). Untuk sampel yang tidak mendapatkan imunisasi BCG terdapat 9 anak, terdiri dari 8 anak $(88.9 \%)$ yang mengalami tuberkulosis dan 1 orang anak $(11.1 \%)$ yang tidak mengalami tuberkulosis.

Hasil tabulasi silang pada hubungan antara status imunisasi BCG dengan tuberkulosis pada anak didapatkan nilai Chi-square hitung sebesar 6.444 dengan signifikansi sebesar 0.011. Hal ini menunjukkan bahwa terdapat hubungan yang signifikan antara status imunisasi dengan tuberkulosis pada anak karena nilai Chi-square hitung lebih besar dari pada Chi-square tabel (3.841) dan nilai signifikansi lebih kecil dari 0.05 .

Dari tabel 5.4 di atas dilakukan perhitungan Odd ratio untuk melihat hubungan antara faktor risiko dengan penyakit, dalam hal ini melihat faktor risiko imunisasi BCG dengan tuberkulosis pada anak. Hasil perhitungan Odd ratio status imunisasi BCG dengan tuberkulosis pada anak adalah 0.094 . Odds ratio tersebut menggunakan interval kepercayaan $95 \%$ dengan batas bawah 0.011 dan batas atas 0.808 . Nilai OR $<1$ menandakan jika imunisasi BCG merupakan faktor penghambat atau faktor protektif.

Menurut perhitungan Chi-square didapatkan data nilai Contingency Coefficient sebesar 0.316 dengan signifikansi 0.011. Berdasarkan nilai tersebut dapat ditemukan nilai PAR (Population Attributable Risk) $=10 \%$.

Berdasarkan data tersebut secara statistik terdapat hubungan yang signifikan antara pemberian imunisasi BCG dengan kejadian tuberkulosis pada anak di Puskesmas Pandian Kabupaten Sumenep. Hal ini dibuktikan dengan 
hasil analisis tabulasi silang pada hubungan antara status imunisasi BCG dengan tuberkulosis pada anak nilai Chi-square hitung sebesar 6.444 dengan signifikansi sebesar 0.011, nilai Chi-square hitung lebih besar dari pada Chi-square tabel (3.841) dan nilai signifikansi lebih kecil dari 0.05 .

Hasil penelitian ini sejalan dengan penelitian yang dilakukan Livana dan Muniarsih (2007) yang menyatakan bahwa ada hubungan antara pemberian imunisasi BCG pada anak dengan kejasian tuberkulosis. Penelitian yang dilakukan Briassoulis et al. (2005) menyatakan bahwa imunisasi BCG tidak sepenuhnya melindungi anak dari serangan tuberkulosis. Pernyataan tersebut juga sejalan dengan hasil yang diperoleh pada penelitian ini, anak yang sudah diimunisasi BCG ternyata juga bisa terkena tuberkulosis. Imunisasi BCG tidak mencegah penyakit tuberkulosis primer tapi mencegah terjadi komplikasi yang lebih berat dari tuberkulosis, misalnya meningitis TB dan efusi pleura (Said \& Boediman, 2010).

Pada penelitian yang telah dilakukan, anak yang yang sakit tuberkulosis sebagian besar sudah mendapatkan imunisasi BCG karena merupakan imunisasi yang wajib pada anak. Pemberian imunisasi BCG saat ini berdasarkan jadual imunisasi IDAI 2012 diberikan pada umur 2-3 bulan (IDAI, 2012).

Anak yang tidak mendapatkan imunisasi BCG diperoleh dari anak yang bertempat tinggal jauh dari fasilitas kesehatan yang memadai, orang tua dengan tingkat pendidikan rendah (antara SD-SMP), orang tua yang tidak tahu dengan informasi imunisasi BCG dan orang tua yang tidak ingin anaknya diimunisasi. Anak yang sudah mendapatkan imunisasi BCG dan sakit tuberkulosis besar kemungkinan dipengaruhi oleh faktor risiko lain yang menyebabkan anak terinfeksi dan menjadi sakit. Faktor-faktor risiko tuberkulosis antara lain kontak dengan pasien tuberkulosis dewasa yang erat, status gizi anak yang rendah sehingga sistem imun tubuh tidak maksimal, kepadatan hunian yang memungkinkan penyakit infeksi menular dengan cepat, kelembapan udara yang tinggi yang membuat bakteri tuberkulosis berkembang dengan baik dan keadaan lingkungan yang tidak bersih (Kuswantoro, 2002).

Berdasarkan analisis berikutnya didapatkan Odds Ratio $(\mathrm{OR})=0.094$ dengan interval kepercayaan 95\% $=0.011$ 0.808 . Karena nilai Odds ratio $<1$ dan rentang interval kepercayaan tidak mencakup angka 1, hal ini berarti faktor yang diteliti, yaitu imunisasi BCG merupakan faktor protektif. Jadi, imunisasi BCG merupakan faktor protektif kejadian tuberkulosis pada anak, artinya anak yang mendapatkan imunisasi BCG memiliki risiko untuk menderita tuberkulosis 0.094 kali dibandingkan dengan anak yang belum mendapatkan imunisasi BCG.

Pada analisis Chi-square juga didapatkan data nilai Contingency Coefficient sebesar 0.316 dan signifikansi sebesar 0.011 , dengan nilai tersebut ditemukan nilai PAR sebesar $10 \%$. Nilai tersebut menggambarkan bahwa imuinisasi BCG pada populasi sampel dapat mencegah terjadi tuberkulosis pada anak sebesar $10 \%$ kasus tuberkulosis.

\section{KESIMPULAN}

Berdasarkan penelitian yang telah dilakukan maka dapat disimpulkan bahwa hasil yang diperoleh adalah ada hubungan yang bermakna secara statistik antara pemberian imunisasi BCG dengan kejadian tuberkulosis pada anak di Puskesmas Pandian Kabupaten Sumenep, imunisasi BCG merupakan faktor protektif terhadap terjadinya tuberkulosis pada anak dengan nilai proteksi sebesar 0.094, dan imunisasi BCG dapat mencegah tuberkulosis sekitar 10\% kasus pada populasi sampel.

\section{DAFTAR PUSTAKA}

Baharudin, M., 2010. Buku Blok Neuromuscular Ilmu Penyakit Saraf. Malang: UMMPress, pp. 141-142

Baratawidjaja, K. G. \& Rengganis, I., 2010. Imunologi Dasar Edisi Ke-9. Jakarta: Balai Penerbit FKUI, pp. 570-577; 407-410

Briassoulis, G., Karabatsou, I., Gogoglou, V. \& Tsorva, A., 2005. BCG Vaccination at Three Different Groups: Response and Effectiveness. Journal Of Immune Based Therapies And Vaccines, Volume 3, pp. 1-4.

Brooks, G. F., Carroll, K. C., Butel, J. S. \& Morse, S. A., 2007. Jawetr, Melnick, \& Adelberg's Medical Microbiology 24th Edition Chapter 24 : Mycobacteria, USA: McGrawHill Companies.

DEPKES RI, 2009. Kategori Umur, Jakarta: DEPKES.

Dinkes Jatim, 2012. Data Program Pengendalian Penyakit Menular di Jawa Timur, Surabaya: Dinkes Jatim.

Djuanda, A., 2009. Tuberkulosis Kutis. Dalam: A. Djuanda, M. Hamzah \& S. Aisah, penyunt. Ilmu Penyakit Kulit dan Kelamin Edisi Ke-5. Jakarta: Balai Penerbit FKUI, pp. 64-65.

Fitriani, E., 2012. Faktor Risiko yang Berbubungan dengan Kejadian Tuberkulosis Paru (Studi Kasus di Puskesmas Ketanggungan Kabupaten Brebes Tabun 2012), Semarang: Fakultas Ilmu Kesehatan Masyarakat Universitas Negeri Semarang.

Herawati, M. H., Rahajoe, N. N., Tarigan, L. H. \& Adisasmita, A. C., 2002. Kejadian Tuberkulosis pada Anak Setelah Imunisasi Bacillus Calmette et Guerin di 5 Wilayah Puskesmas Kecamatan Jatinegara Jakarta Timur Tahun 2000-2002. Buletin Penelitian Kesehatan, Vol. 33(No. 1), pp. 32-40.

IDAI, 2012. Jadwal Imunisasi 2011-2012 Rekomendasi Ikatan Dokter Anak Indonesia, s.l.: s.n.

Islamiyati \& Fairus, M., 2009. Faktor-faktor yang Mempengaruhi Kejadian Tuberkulosis Paru pada Balita di Poliklinik Anak RSU A. Yani Metro Tahun 2009. Jurnal Kesehatan Metro Sai Wawai, Volume 11, pp. 6370.

Kartasamita, C. B., 2009. Epidemiologi Tuberkulosis Anak. Sari Pediatri, Volume 11, pp. 124-128.

Kartasasmita, C. B. \& Basir, D., 2010. Epidemiologi Tuberkulosis. Dalam: N. N. Rahajoe, B. Supriyatno \& D. B. Setyanto, penyunt. Buku ajar Respirologi Anak Edisi Pertama. Jakarta: Badan Penerbit IDAI, pp. 162165.

Kaswandani, N., Setyanto, D. B. \& Rahajoe, N. N., 2010. Akurasi Polymerase Chain Reaction (PCR) 
Dibandingkan dengan Uji Tuberkulin untuk Diagnosis Tuberkulosis pada Anak. Sari Pediatri, Volume 12, pp. 42-45.

Kenyorini, Suradi \& Surjanto, E., 2006. Uji Tuberkulin. Jurnal Tuberkulosis Indonesia, Volume 3, pp. 1-4.

Kusuma, H. C. \& Setiawati, L., 2010. Imunologi Infeksi Mycobacterium tuberculosis. Dalam: N. N. Rahajoe, B. Supriyatno \& D. B. Setyanto, penyunt. Buku Ajar Respirologi anak Edisi Pertama. Jakarta: badan Penerbit IDAI, pp. 188-191.

Kuswantoro, 2002. Faktor-faktor yang Berbubungan dengan Kejadian TB Paru Primer pada Anak Balita, Semarang: Fakkultas Kedokteran Universitas Dipenogoro.

Levinson, W., 2010. Review of Medical Microbiology \& Immunology 11th Edition Chapter 21 : Mycobacteria, San Fransisco: McGraw-Hill Companies.

Muniarsih, E. \& Livana, 2007. Hubungan Pemberian Imunisasi BCG dengan Kejadian Tuberkulosis Paru di Balai Pengobatan Penyakit Paru Ambarawa Tahun 2007. Jurnal Kesehatan Surya Medika.

Petri, W. A., 2008. Senyawa Antimikroba (Lanjutan), Obatobat yang Digunakan pada Kemoterapi Tuberkulosis, Penyakit Kompleks Akibat M. avium dan Lepra. Dalam: J. G. Hardman \& L. E. Limbird, penyunt. Dasar Farmakologi Terapi Volume 2. Jakarta: EGC, pp. 10481049.

Price, S. A. \& Standridge, M. P., 2006. Tuberkulosis Paru. Dalam: S. A. Price \& L. M. Wilson, penyunt. Patofisiologi, Konsep Klinis dan Proses-proses Penyakit Edisi 6. Jakarta: EGC, pp. 852-853.

Prince, A., 2010. Bab 10 Penyakit Infeksi. Dalam: R. E. Berhman \& R. M. Kliegman, penyunt. Nelson Esensi Pediatri Edisi 4. Jakarta: EGC, pp. 431-435.

Proverawati, A. \& Andhini, C. S. D., 2010. Imunisasi dan Vaksinasi. Yogyakarta: Nuha Offset.

Rahajoe, N. N., Basir, D., MS, M. \& Kartasasmita, C. B., 2008. Pedoman Nasional Tuberkulosis Anak Edisi Ke-2 dengan Revisi. Jakarta: UKK Respirologi PP IDAI.

Rahajoe, N. N. \& Setiawati, L., 2010. Tatalaksana TB. Dalam: N. N. Rahajoe, B. Supriyatno \& D. B. Setyanto, penyunt. Buku Ajar Respirologi Anak Edisi Pertama. Jakarta: Badan Penerbit IDAI, pp. 214-217.

Rahajoe, N. N. \& Setyanto, D. B., 2010a. Diagnosis Tuberkulosis pada Anak. Dalam: N. N. Rahajoe, B. Supriyatno \& D. B. Setyanto, penyunt. Buku Ajar Respirologi Anak Edisi Pertama. Jakarta: Badan Penerbit IDAI, pp. 194-213.

Rahajoe, N. N. \& Setyanto, D. B., 2010b. Patogenesis dan Perjalanan Alamiah. Dalam: N. N. Rahajoe, B. Supriyatno \& D. B. Setyanto, penyunt. Buku Ajar Respirologi Anak Edisi Pertama. Jakarta: Badan Penerbit IDAI, pp. 169-171.

Safithri, F., 2011. Diagnosis Tuberkulosis Dewasa dan Anak Berdasarkan ISCT (International Standart for Tuberculosis Care). Saintika Medika, Jurnal Bidang Kedokteran dan Kesehatan, Volume 7, pp. 63-66.

Said, M. \& Boediman, I., 2010. Imunisasi BCG pada Anak. Dalam: N. N. Rahajoe, B. Supriyatno \& D. B. Setyanto, penyunt. Buku Ajar Respirologi Anak Edisi Pertama. Jakarta: Badan Penerbit IDAI, pp. 252-255.
Sari, D. N., 2009. Faktor Risiko Kejadian TB Paru pada Anak yang Sudah Diimunisasi BCG (Studi di RS Khusus Paru Surabaya), Surabaya: Fakultas Ilmu Kesehatan Masyarakat Universitas Airlangga.

Schluger, N. W. \& Rom, W. N., 1998. The Host Immune Response to Tuberculosis. American Journal of Respiratory and Critical Care Medicine, Volume 157, pp. 679691.

Setyanto, D. B., Supriyatno, B., Kaswandani, N. \& Widyaningsih, R., 2005. Uji Interferon Gamma untuk Deteksi Infeksi TB pada Anak, Semarang: Jurnal Kesehatan Media Medika Indonesiana FK UNDIP. Tahun 2005 Volume 40 No 2.

Starke, J. R., 2011. Tuberculosis (Mycobacterium tuberculosis). Dalam: R. M. Kliegman, et al. penyunt. Nelson Textbook of Pediatrics 19th Edition. Philadelphia: Elsevier.

Suradi, R. et al., 2011. Studi Kasus-Kontrol. Dalam: S. Sastroasmoro \& S. Ismael, penyunt. Dasar-dasar Metodologi Penelitian Klinis. jakarta: Sagung Seto, pp. 146-147.

Tjahajati, I., 2005. Vaksinasi BCG Meningkatkan Aktivitas Fagositosis Dan Sekresi Reactive Oxygen Intermediate (ROI) Pada Makrofag Peritoneum Kucing Yang Diinfeksi Dengan Mycobacterium Tuberculosis. Jurnal Kedokteran Brawijaya, Volume 21.

WHO, 2013a. Global Tuberculosis Report 2013. s.l.:s.n.

WHO, 2013b. Pocket Book of Hospital Care for Children, Guidelines for Management of Common Childhood Illnesses Second Edition. s.l.:s.n. 